\title{
Hormonal Status of Females in Reproductive Age Group with Benign Breast Disease: A Study of 150 Cases
}

\author{
Talukdar MMI' ${ }^{1}$ Ahmed N ${ }^{2}$, Azad MAK ${ }^{3}$, Khan MEH ${ }^{4}$, Chowdhury F ${ }^{5}$, Lima IJ ${ }^{6}$, Parvin S $^{7}$
}

Conflict of Interest: None Contributions by Authors: All authors contributed form protocol preparation upto manuscript writing

Received: 06 August 2016

Accepted: 10 November 2016

www.banglajol.info/index.php/JSSMC

\section{Key Words:}

Benign breast disease, oestrogen, testosterone,prolactin.

\section{Abstract:}

Background: Benign disorder of breast in female usually seen in reproductive period of life, is thought to be largely hormone induced and there is a dramatic fall in the incidence after menopause due to cessation of ovarian stimulation.

Objectives: To find out the relationship between different types of benign breast disease and hormones acting on breast mainly oestrogen, testesteron and prolactin.

Methodology: This is a prospective observational study conducted in the department of surgery, Shaheed Suhrawardy Medical College Hospital. Total 150 female patients of reproductive age were included in the study. Serum levels of oestrogen, testosterone and prolactin were done in all patients. Other relevant radiological and cytological investigations were done accordingly where indicated.

Results: Mean age of the study subjects were $28 \pm 8.46$ years. Among the study subjects 64 (42.7\%) patients used hormonal contraception, on the other hand 86 patients $(57.3 \%)$ did not used hormonal contraceptive. 68 (45.3\%) patients were non parous, 29(19.3\%) were primi parous and 53 (35.3\%) were multiparous. 87 (58\%) had positive history of breast feeding, 63 (42\%) patients did not breast fed their babies. Fibrocystic disease was most common diagnosis among study group followed by fibroadenoma. 96 (64\%) patients had fibrocystic disease followed by $38(25.3 \%)$ had fibroadenoma. Mean oestrogen, testosterone and prolactin level was $71.16 \pm$ $57.63 \mathrm{pg} / \mathrm{ml}, 0.59 \pm 0.42 \mathrm{nmol} / \mathrm{L}$ and $22.61 \pm 16.65 \mathrm{ng} / \mathrm{ml} \mathrm{respectively.}$

Conclusion: With this small sample size it is difficult to conclude regarding relation between oestrogen, testosterone, prolactin and benign breast disease. But this study can be used as a base line document regarding benign breast disease, hormone profile, type, distribution and frequency of benign breast disease.

[J Shaheed Suhrawardy Med Coll 2016; 8(2): 54-57] DOI: http://dx.doi.org/10.3329/jssmc.v8i2.37244

\section{Introduction}

Breast is a dynamic structure which undergoes changes throughout women's reproductive life, and superimposed on this cyclical changes throughout menstrual cycle. Both

1. Dr. Md. Monoarul Islam Talukdar, Resident Surgeon (Surgery), Shaheed Suhrawardy medical college hospital, Dhaka.

2. Dr. Nadim Ahmed, Senior Consultant (Surgery), Shaheed Suhrawardy Medical College Hospital, Dhaka.

3. Dr. Md. Abul Kalam Azad, Assistant Professor (Surgery), Shaheed Suhrawardy Medical College Hospital, Dhaka.

4. Dr. Mohammad Emrul Hasan Khan, Assistant Professor (Surgery), Shaheed Suhrawardy Medical College Hospital, Dhaka.

5. Dr. Fayem Chowdhury, Registrar (Surgery), Shaheed Suhrawardy medical college hospital, Dhaka.

6. Dr. Ismat Jahan Lima, Junior Consultant (Surgery), Shaheed Suhrawardy Medical College Hospital, Dhaka.

7. Dr. Sultana Parvin, Indoor Medical Officer (Surgery), Shaheed Suhrawardy Medical College Hospital, Dhaka.

Correspondence: Dr. Md. Monoarul Islam Talukdar, Resident surgeon (Surgery), Shaheed Suhrawardy medical college hospital, Dhaka. Address- Flat- 12/D, Urban diganta, 64 Green road, Dhaka. Mobile-01711193118 E mail-drmdmonoarul@gmail.com benign and malignant lesion is very frequent to affect breast with various morphology. Non cancerous disease of the breast have assumed increasing importance because of the public awareness of the breast cancer. ${ }^{1}$ Globally benign pathological states accounts for approximately $90 \%$ of the clinical presentation related to the breast. $^{2}$ It is therefore important for surgeons, pathologists and oncologists to recognize benign lesions, both to distinguish them from in situ and invasive breast cancer and to assess a patient's risk of developing breast cancer, so that the most appropriate treatment modality for each case can be established. ${ }^{3}$ The cyclical changes due to variations in estrogen and progesterone result in increased mitosis around days 22-24 of the menstrual cycle but apoptosis restores the balance across the cycle. ${ }^{4}$ Incidence of benign lesions is common in the second decade reaching on its peak at fourth and fifth decade of life $^{3}$. Risk factors 
for benign and malignant breast diseases include low parity, nulliparity, low age at first birth and late menopause, highlighting the fact towards excessive circulating estrogen levels. ${ }^{5}$ Other hormones thought to have relation with spectrum of benign breast disease are progesterone, Lactogenic hormone- Prolactin, Insulin like growth factor 1(IGF 1), Thyrotropin

releasing hormone (TRH), Pituitary hormones- Follicle stimulating hormone (FSH) and Leutinizing hormone (LH). Infact FSH and LH indirectly affect breast physiology by controlling Ovarian hormones.

This descriptive type of cross sectional study was carried out in out patient department of Shaheed Suhrawardy medical college hospital, Dhaka over a period of one and half year starting from January 2015 to June 2016. A total of 150 patients diagnosed with benign breast disease were included in the study. Data were collected by nonrandom biased sampling with the help of preformed data sheet from patients of reproductive age group who gave informed written consent. Serum level of oestrogen, testesteron and prolactine were done after detail history and clinical examination. At the end of the study data were compiled and analyzed. Then the results were presented in different tables.

\section{Statistical method:}

Obtained data was analyzed digitally with SPSS 20 (Social Package Statistical Service). Quantitative data was expressed as Mean $\pm \mathrm{SD}$.

\section{Results}

Table I

\begin{tabular}{lll}
\multicolumn{3}{c}{ Showing outcome of the study } \\
Serial & Variable & Result \\
\hline 1 & Age & $28 \pm 8.46$ years \\
2 & Parity & Non parous- $68(45.3 \%)$ \\
& & Primi para- $29(19.3 \%)$ \\
& & Multiparous- $53(35.3 \%)$ \\
3 & Lactation & Yes- $87(58 \%)$ \\
& & No- $63(42 \%)$ \\
4 & Contraceptive use & Yes- $64(42.7 \%)$ \\
& & No- $86(53.7 \%)$ \\
5 & Level of estradiol & $71.16 \pm 57.62 \mathrm{pg} / \mathrm{ml}$ \\
6 & Level of testosterone & $0.59 \pm 0.42 \mathrm{nmol} / \mathrm{L}$ \\
7 & Level of prolactin & $22.60 \pm 16.65 \mathrm{ng} / \mathrm{ml}$ \\
8 & Age of menarche & $12.67 \pm 0.86 \mathrm{years}$ \\
\hline
\end{tabular}

\section{Table II}

Age distribution of the study subjects.

\begin{tabular}{lc} 
Age & (Years) \\
\hline Range & $13-58$ years \\
Mean \pm SD & $28 \pm 8.46$ years \\
\hline
\end{tabular}

Table III

Contraceptive use among study population

\begin{tabular}{lc} 
Contraceptive use & Result \\
\hline Yes & $64(42.7 \%)$ \\
No & $86(57.3 \%)$ \\
\hline
\end{tabular}

Table IV

Table showing type of disease among the study population

\begin{tabular}{lc} 
Name & Number \\
\hline Fibroadenoma & $38(25.3 \%)$ \\
Granulomatous mastitis & $02(1.3 \%)$ \\
Mastalgia & $02(1.3 \%)$ \\
Fibrocystic disease & $96(64 \%)$ \\
Duct ectasia / periductal mastitis & $06(4 \%)$ \\
Fibroadenoma with Fibrocystic disease & $05(3.3 \%)$ \\
Galactocele & $1(0.3 \%)$ \\
\hline
\end{tabular}

Table V

Serum estradiol level among study subjects.

\begin{tabular}{ll} 
Serum Estradiol $(\mathrm{pg} / \mathrm{ml})$ & $(26.6-161 \mathrm{pg} / \mathrm{ml})$ \\
Range & $9.52-397 \mathrm{pg} / \mathrm{ml}$. \\
Mean \pm SD & $71.16 \pm 57.63 \mathrm{pg} / \mathrm{ml}$. \\
\hline
\end{tabular}

Table VI

Serum testosterone level among study subjects.

Serum testosterone $(\mathrm{nmol} / \mathrm{L}) \quad(0.5-2.5 \mathrm{nmol} / \mathrm{L})$

Range $\quad 03-2.12 \mathrm{nmol} / \mathrm{L}$

Mean \pm SD

$0.59 \pm 0.42 \mathrm{nmol} / \mathrm{L}$

\section{Table VII}

Serum polactin level among study subjects.

Serum prolactin $(\mathrm{nmol} / \mathrm{L})$

$(2.8-29.2 \mathrm{ng} / \mathrm{ml})$

Range

$3.09-98.43 \mathrm{ng} / \mathrm{ml}$

Mean \pm SD

$22.61 \pm 16.65 \mathrm{ng} / \mathrm{ml}$ 


\section{Table VIII}

\begin{tabular}{lccc}
\multicolumn{4}{c}{ Showing mean oestrogen, testosterone and prolactin value among study population. } \\
\cline { 4 - 4 } Name of disease & Mean estrogen Value & Mean testosterone level & Mean Prolactin value \\
\hline Fibroadenoma & $76.93 \mathrm{pg} / \mathrm{ml}$ & $0.7 \mathrm{nmol} / \mathrm{L}$ & $20.05 \mathrm{ng} / \mathrm{ml}$ \\
Granulomatous mastitis & $37.57 \mathrm{pg} / \mathrm{ml}$ & $0.4 \mathrm{nmol} / \mathrm{L}$ & $10.7 \mathrm{ng} / \mathrm{m}$ \\
Mastalgia & $30.17 \mathrm{pg} / \mathrm{ml}$ & $0.35 \mathrm{nmol} / \mathrm{L}$ & $08.2 \mathrm{ng} / \mathrm{ml}$ \\
Fibrocystic disease & $68.20 \mathrm{pg} / \mathrm{ml}$ & $0.56 \mathrm{nmol} / \mathrm{L}$ & $24.13 \mathrm{ng} / \mathrm{ml}$ \\
Duct ectasia & $78.56 \mathrm{pg} / \mathrm{ml}$ & $0.49 \mathrm{nmol} / \mathrm{L}$ & $19.82 \mathrm{ng} / \mathrm{ml}$ \\
Fibroadenoma with Fibrocystic disease & $94.92 \mathrm{pg} / \mathrm{ml}$ & $0.63 \mathrm{nmol} / \mathrm{L}$ & $27.18 \mathrm{ng} / \mathrm{ml}$ \\
Galactocele & $122 \mathrm{pg} / \mathrm{ml}$ & $0.75 \mathrm{nmol} / \mathrm{L}$ & $16.86 \mathrm{ng} / \mathrm{ml}$ \\
\hline
\end{tabular}

\section{Discussion:}

In this study, clinicopathological type of benign breast disease, level of hormones affect normal breast development and their probable link with benign breast disease were observed. In our study age range of the patients were 13 years to 58 years with the mean age $28 \pm$ 8.46 years. A sub Saharan African tertiary institute study by Okoth $\mathrm{C}$ et al. 2013 showed that their mean age for benign breast disease was 28.4 years6 which is very similar to my study. Probably the same or almost same socio economic condition of the two region of the world brings the almost same result. Moreover this study has similarity with a study held in Pakistan on 2013. ${ }^{7}$

If we consider the mean age of the patients with fibroadenoma; it was 23.61. This is very similar with the other study regarding benign breast disease conducted by Katiyar S \& Nigam S $2013 .{ }^{8}$

In this study contraceptive history of each and every patients were noted meticulously. Patients using barrier or other nonhormonal methods were labeled as patients not using contraceptives. On the other hand patients having oral contraceptive pill, emergency contraceptive pill, Intra muscular hormonal injections and with subdermal implant were labeled as patients using contraceptive. 64 patients among 150 patients, that is $42.7 \%$ uses hormonal product as contraception and 86 (57.3\%) women does not use hormonal contraceptive.

In 2015 unicef published a data where they showed that in south east Asia rate of contraception use is $57-64 \%$. As Bangladesh possesses a male predominant social and familial structure rate of use contraception among male is low unlike other developed countries. In this study we found that $42.7 \%$ woman uses hormonal contraceptive product matches with the data providedby united nation as approximately $15-20 \%$ of our male population uses contraceptive method.
Several author studied with the different type of entity of benign breast disease as it is a vast entity and there are several types. In this study fibroadenoma, granulomatous mastitis, fibrocystic disease, duct ectasia with periductal mastits and galactocele are the types of benign breast disease where we concentrated. Among 150 patients we found $38(25.3 \%)$ patients had fibroadenoma, 96 (64\%) had fibrocystic disease, 6(4\%) patients had duct ectasia/ periductal mastitis. Other types were 2 patients with mastalgia, 2 patients of granulomatous mastitis and 1 patient had galactocele. This data might have some dissimilarity with the data provided by Katiyar S \& Nigam S 2013, Okoth C et al. 20138. But we believe that geographic, social and other factors brings this diversity of benign breast disease among the different part of the world.

In our study youngest patient of fibroadenoma was 14 years old and the eldest patient was 58 years old. Mean age of fibroadenoma patients were 23.61 years and most of the fibroadenoma patients were within the age limit of 20-30 years. This result is near similar with the result of Jayaprashad $\mathrm{N}$ held in india. ${ }^{9}$

Serum oestrogen has several normal values accoding to phase of menstruation. For this reason several author collected blood sample during follicular phase of menstrual cycle, presumably following the common sense notion that it is best to sample the hormones when its level is high. ${ }^{10}$ For this reason we collected all blood sample from 3 rd to 7 th day of follicular phase of menstrual cycle. Range of serum oestrogen level among study populations were $9.52 \mathrm{pg} / \mathrm{ml}-397 \mathrm{pg} / \mathrm{ml}$. Mean \pm SD was $71.16 \pm 57.63 \mathrm{pg} / \mathrm{ml}$. In study of 588 patients conducted in Greece showed that median 10th to 90th percentile of measured oestrogen was $104 \mathrm{pg} / \mathrm{ml}$ in benign breast disease patient. ${ }^{11}$ Where as in our study it was $100 \mathrm{pg} / \mathrm{ml}$ which is very similar to the study of E Samoli et al. 2013. 
In case of fibroadenoma of breast range of serum oestrogen was $14.66-313 \mathrm{pg} / \mathrm{ml}$ with the mean $\pm \mathrm{SD}$ was $76.94 \pm 57.69 \mathrm{pg} / \mathrm{ml}$. And in case of fibrocystic disease range of serum oestrogen level was 9.52 to $397 \mathrm{pg} / \mathrm{ml}$ and mean \pm SD was $68.20 \pm 57.47 \mathrm{pg} / \mathrm{ml}$. Among 38 patients of fibroadenoma 3 (7.89\%) patients had oestrogen level more than normal and $3(7.89 \%)$ patients had oestrogen level lower than normal. This data does not reflect any definitive relation between abnormal oestrogen level with fibroadenoma. In case of fibrocystic disease 10 patients (10.42\%) out 96 patients had oestrogen level lower than normal value and 2 patients $(2.08 \%)$ had oestrogen level more than normal value. There might have some connections between low oestrogen level with fibrocystic disease but this is not possible to comment regarding this connection by this small sample study. It demands more concentration and a large sample study to comment about the connection.

In this study there were 6 patients who were diagnosed as duct ectasia and periductal mastitis. These 6 patients presented with characteristics nipple discharge. Range of oestrogen value among this 6 patients were 23.46 to 193.87 $\mathrm{pg} / \mathrm{ml}$. Mean $\pm \mathrm{SD}$ was $78.56 \pm 67.19 \mathrm{pg} / \mathrm{ml} .1$ patient had oestrogen level below normal value and 1 patient had oestrogen value above normal which denies any hormonal connection.

Five patients in this study had fibroadenoma in one breast and fibrocystic disease in opposite breast. Regarding this patient Mean \pm SD of serum oestrogen level was $94.92 \pm$ 72.92 with range of $17.92-201.19 \mathrm{pg} / \mathrm{ml} .1$ patient had oestrogen level below normal and 1 patient had oestrogen level above normal. Mean oestrogen level for fibroadenoma with fibrocystic disease is higher than the mean oestrogen level for single fibroadenoma or fibrocystic disease.In this study women who fulfilled inclusion and exclusion criteria; serum testosterone level were measured. Blood sample were drawn in days 3-7 day of the follicular phase of the menstrual cycle and after an 8-hour fast. Range of serum testosterone level among study populations were .03 to $2.12 \mathrm{nmol} / \mathrm{L}$. Mean $\pm \mathrm{SD}$ was $0.59 \pm 0.42 \mathrm{nmol} / \mathrm{L}$.

Range of Serum prolactin level among the study subjects were 3.09 to $98.43 \mathrm{ng} / \mathrm{ml}$ with mean $\pm \mathrm{SD}$ was $22.61 \pm 16.65$ $\mathrm{ng} / \mathrm{ml}$. Among the study populations 22 patients had prolactin level higher than normal which is $14.67 \%$. Aisha M et al. 2007 showed in their study that $30 \%$ of their study subjects had higher prolactin level in benign breast disease $^{12}$ in case of Pakistani women.Probably the geographic variation among study subjects brings this diversity in our result.
The rationality of the study is to reveal the hormonal connection with benign breast disease which can prevent undue surgical treatment as well as blind hormonal treartment for benign breast disease. Though in some patients hormone level has some alterations from normal value but this study is not conclusive to establish the relationship between benign breast disease and oestrogen, testosterone and prolactin. Further study with large sample size might establish relation between these three hormone and benign breast disease.

\section{References:}

1. Vaidyanathan L, Barnard K, Elnicki D.M: Benign breast disease: when to treat, when to reassure, when to refer. Cleve Clin J Med 2002, 69(5):425-432.

2. Louis J, Jekel H: Aberations in the normal development and involution of the breast (ANDI). Am. J. epidemiol 1997;145: 1030-8.

3. Guray M, Sahin A.A: Benign breast diseases: classification, diagnosis and management. Oncologist 2006, 11(5):435449 .

4. Hughes L.E, Mansel R.E \& Webster D.J.T. Abberation of normal development and involution (ANDI):A new perspective in pathogenesis and nomenclature of benign breast disorders. The Lancet 1987;1316-1319.

5. Hislop T, Elwood J: Risk factors for benign breast disease: a 30-yearcohort study. Can Med Assoc J 1981, 124(3):283.

6. Okoth, C., Galukande, M., Jombwe, J., \& Wamala, D.: Benign proliferative breast diseases among female patients at a sub Saharan Africa tertiary hospital: a cross sectional study. BMC Surgery 2013; 13(9):1-5.

7. Hafiz, M,A., Shafaq, S., Hiba, A, S., Nazish, S., Anum, M., \& Ribak, U.: Clinicopathological profile of patients with breast diseases. Diagnostic Pathology 2013;8:77:

8. Katiyar S, Nigam S: Clinico-pathological spectrum of benign breast diseases in \&around kanpur. Journal of Advance Researches in Biological Sciences, 2013, Vol. 5 (2) 154-158.

9. Jayaprashad, N.,2012. Clinical study of benign breast diseases. MS Thesis. Rajiv Gandhi University of Health Sciences, Karnataka, Bangalore.10. Naseer, A., Tessa, M., Pollard, U., Nigel, U. ; The Optimal Timing of Blood collection During the Menstrual Cycle for the Assessment of Endogenous Sex hormones ; Can Interindividual Differences in Levels Over the Whole Cycle be assessed on a Single Day. Cancer Epidemiol Biomarkers Prev 2002;11;147-151.

11. E, Samoli., D, Trichopoulos., A, Lagiou., P, Zourna., C, Georgila., P, Minaki., A, Barbouni., D, Vassilarou., A, Tsikkinis., C, Sfikas., E, Spanos., and P, Lagiou.: The hormonal profile of benign breast disease. British Journal of Cancer (2013) 108, 199-204 | doi: 10.1038/bjc.2012.493.

12. Aisha, M., Shahida,P., Sangrasi,A,K.,Arshad,M,M.,Aziz, L., \& Altaf, H,T.: Clinical presentation and Prolactin level of ANDI (aberration of normal development and involution) patients of breast. World Journal of Medical Sciences 2007:2(2);83-87.4 